\title{
Seasonal changes of violaxanthin cycle pigment de-epoxidation in wintergreen and evergreen plants*
}

\author{
Olga Dymova ${ }^{\bowtie}$ and Tamara Golovko \\ Institute of Biology, Komi Science Centre, Ural Branch of Russian Academy of Sciences, Syktyvkar, Russia
}

\begin{abstract}
We studied carotenoids composition and the activities of the xanthophylls pigments in evergreen conifers (Abies sibirica, Juniperus communis, Picea obovata) and dwarfshrub (Vaccinium vitis-idaea), and in wintergreen herbaceous plants (Ajuga reptans, Pyrola rotundifolia) growing near Syktyvkar $\left(61^{\circ} 67^{\prime} \mathrm{N} 50^{\circ} 77^{\prime}\right.$ E). The carotenoid pool consisted mainly of following xanthophylls: lutein (70\%), neoxanthin (7-10\%) and a xanthophylls cycle component - violaxanthin (3-15\%). Zeaxanthin and antheraxanthin were found in conifer samples collected in December-March while in other species - during all year. A direct connection between xanthophyll pigment deepoxidation level and light energy thermal dissipation was shown only for boreal conifer species. It is proposed that zeaxanthin plays a central role in the dissipation of excess excitation energy (nonphotochemical quenching) in the antenna of photosystem II (PSII). We conclude that the increase in the extent of de-epoxidation is beneficial for the retention of PSII activity for conifers in early spring and for herbs in summer.
\end{abstract}

Key words: carotenoids, xanthophyll cycle, de-epoxidation state

Received: 14 October, 2011; accepted: 01 March, 2012;

available on-line: 17 March, 2012

\section{INTRODUCTION}

The phenomenon of overwintering with green leaves is characteristic of evergreen and wintergreen plant species. Such species often experience photoinhibition during autumn-winter and early spring periods, when photosynthetically active radiation (PAR) absorbed by leaves cannot be completely utilized for $\mathrm{CO}_{2}$ assimilation because of low ambient temperature. Carotenoids (Car) are known to play a major role in the photosynthetic apparatus (PSA) protection. Car stabilize chloroplast membranes, can quench triplet chlorophyll and singlet oxygen. A better phototolerance appears to be frequently associated with an increase of the xanthophyll cycle pool of pigments. Xanthophyll cycle (XC) takes place on the light-harvesting complex (LHC) proteins (Thayer \& Bjorkman, 1992). XC pigments, especially, zeaxanthin, play an important role by dissipating excess energy absorbed by the LHC complexes of photosystem II (LHC PS II) (Demmig et al., 1987). Information on the functioning of Car protective mechanism in various species and ecological groups are important for understanding plant adaptation processes.

The aim of this work was to study the seasonal changes of Car as well as to assess the activities of the $\mathrm{XC}$ in the underwood of evergreen conifers (Abies sibirica, Juniperus communis, Picea obovata), in understory ev- ergreen dwarf-shrub (V accinium vitis-idaea), and in wintergreen herbaceous plants (Ajuga reptans, Pyrola rotundifolia) growing in the middle taiga subzone of the European North-East.

\section{MATERIALS AND METHODS}

Plant material was collected from sun exposed and shaded sites what located in coniferous forests near Syktyvkar $\left(61^{\circ} 67 / \mathrm{N} 50^{\circ} 77^{\prime} \mathrm{E}\right)$. The experiments were performed in 2007-2008. Winter- and summer-green leaves, and two-year-old needles were used in the experiments. Leaf samples were frozen in liquid nitrogen and stored at $-76^{\circ} \mathrm{C}$. Separations and quantifications of Car were carried out by reserved-phase high-performance liquid chromatography (HPLC) (Knauer, Germany). The deepoxidation level of XC pigments was calculated from equation: DEPS $=(\mathrm{Z}+0.5 \mathrm{~A}) /(\mathrm{Z}+\mathrm{A}+\mathrm{V})$, when $\mathrm{Z}$ — zeaxanthin, A — antheraxanthin, $\mathrm{V}$ - violaxanthin.

\section{RESULTS AND DISCUSSION}

The total Car content varied in range 500-2800 $\mu \mathrm{g} / \mathrm{g}$ DW in dependence on plant species and consisted mainly of xanthophylls (up to $90 \%$ of the total Car) independently of species and season. Among the xanthophylls, the part of lutein was $70-75 \%$, neoxanthin — near $10 \%$, and violaxanthin - up to $15 \%$. In conifers the level of DEPS of XC pigments was highest in winter and early spring (Table 1). In May it decreased, and in July the deepoxidation was strongly inhibited. On the contrary the understory herbs and shrubs were characterized by the maximum values of DEPS in summer as compared to woody plants.

We found out that the shade-tolerant species A. reptans grown in sunny habitats increased in the pool of XC pigments up to 60\% in July (Dymova et al., 2010). In summer (July) the leaves of sun plants contained considerably greater amounts of the components of the XC cycle - antheraxanthin and zeaxanthin, than the leaves of shade plants (Table 2), as had previously been reported by Demmig-Adams \& Adams (1992). The shade plants were characterized by accumulation of violaxanthin and lutein. $\beta$-carotene content was similar in leaves of sun and shade plants. Under strong light exposure the level of de-epoxidation in shade plants changed insignifi-

e-mail: dymovao@ib.komisc.ru

*Presented at the 16th International Symposium on Carotenoids, 17-22 July, 2011, Kraków, Poland

Abbreviations: Car, carotenoids; LHC, light-harvesting complex; PAR, photosynthetically active radiation; PSA, photosynthetic apparatus; XC, xanthophyll. 
Table 1. Seasonal changes of de-epoxidation state in wintergreen and evergreen plants (\%).

\begin{tabular}{|c|c|c|c|c|c|c|c|}
\hline \multirow{2}{*}{ Month } & \multirow{2}{*}{$\begin{array}{c}\text { Picea } \\
\text { obovata }\end{array}$} & \multirow{2}{*}{$\begin{array}{l}\text { Abies } \\
\text { sibirica }\end{array}$} & \multirow{2}{*}{$\begin{array}{l}\text { Juniperus } \\
\text { communis }\end{array}$} & \multirow{2}{*}{$\begin{array}{l}\text { Vaccinium } \\
\text { vitis-idaea }\end{array}$} & \multirow{2}{*}{$\begin{array}{c}\text { Pyrola } \\
\text { rotundifolia }\end{array}$} & \multicolumn{2}{|c|}{ Ajuga reptans } \\
\hline & & & & & & sun & shade \\
\hline III & 54 & 46 & 60 & 13 & - & - & - \\
\hline V & 12 & 23 & 21 & 18 & 29 & 12 & 7 \\
\hline VII & 0 & 2 & 0 & 19 & 17 & 56 & 7 \\
\hline IX & 13 & 0 & 3 & 9 & 6 & - & - \\
\hline XII & 53 & 30 & 38 & 17 & 10 & 4 & 3 \\
\hline
\end{tabular}

Table 2. Relative content of carotenoid composition in leaves of sun and shade Ajuga reptans plants (\%).

\begin{tabular}{|c|c|c|c|c|c|c|c|}
\hline Month & Plants & Neo & Vio & Ant & Lut & Zea & $\beta$-car \\
\hline \multirow[t]{2}{*}{ V } & Sun & 6.0 & 13.0 & 3.0 & 60.4 & 0.6 & 17.0 \\
\hline & Shade & 7.0 & 11.7 & 1.1 & 65.5 & 0.3 & 14.4 \\
\hline \multirow[t]{2}{*}{ VII } & Sun & 6.8 & 4.2 & 8.6 & 54.8 & 6.8 & 18.7 \\
\hline & Shade & 8.2 & 9.5 & 1.2 & 61.4 & 0.1 & 19.6 \\
\hline \multirow[t]{2}{*}{$X$} & Sun & 7.7 & 10.8 & 0.7 & 66.4 & 0.1 & 14.3 \\
\hline & Shade & 6.8 & 11.0 & 0.6 & 64.1 & - & 17.5 \\
\hline \multirow[t]{2}{*}{ XII } & Sun & 8.9 & 12.2 & - & 62.3 & - & 16.6 \\
\hline & Shade & 8.4 & 13.2 & 1.1 & 61.5 & 0.1 & 15.7 \\
\hline
\end{tabular}

Pigments: Neo, neoxanthin; Vio, violaxanthin; Ant, antheraxanthin; Lut, lutein; Zea, zeaxanthin; $\beta$-car, $\beta$-carotene.

cantly. During transfer of Ajuga plants to light exposed stands, shade-type leaves died as a result of photooxidative damages and then, sun-type leaves were formed. After long-term adaptation of Ajuga leaves to high irradiance, plants characterized by a larger xanthophylls pool and zeaxanthin formation (Dymova \& Golovko, 2007). Zeaxanthin plays a central role in different photoprotective mechanism of chloroplasts.

A strong positive correlation between thermal dissipation of light energy and DEPS was shown for the evergreen conifers (Yatsko et al., 2011). The DEPS level was significantly higher in evergreen plants during winter. The main protective mechanism includes zeaxanthin-dependent thermal energy dissipation of excess light within the LHC PS II.

So, our data have shown that the primary photoprotective mechanism in adaptation evergreen and wintergreen life forms of plants to northern environments is the increase in the degree of the de-epoxidation state of the xanthophylls cycle and the accumulation of zeaxanthin. It provides the harmless dissipation of excess excitation energy in the photochemical system.

\section{Acknowledgements}

This work was supported by the grant from the Ural Branch of the Russian Academy of Sciences (12-Y-41008).

\section{REFERENCES}

Demmig-Adams B, Adams III WW (1992) Carotenoid composition in sun and shade leaves of plants with different life forms. Plant Cell Environ 15: 411-419.

Demmig B, Winter K, Krűger A, Czygan FC (1987) Photoinhibition and zeaxanthin formation in intact leaves. A possible role of the xanthophyll cycle in the dissipation of excess light. Plant Physiol 84: $218-224$.

Dymova OV, Golovko TK (2007) Pigments apparatus in Ajuga reptans plants as affected by adaptation to light growth conditions. Russ J Plant Phys 54: 39-45.

Dymova OV, Grzyb J, Golovko TK, Strzalka K (2010) Characterization of pigment apparatus in winter-green and summer-green leaves of a shade-tolerant plant Ajuga reptans. Russ I Plant Phys 57: 755-763.

Yatsco YN, Dymova OV, Golovko TK (2011) Violaxanthin cycle pigments de-epoxidation and thermal dissipation of light energy in three boreal species of evergreen conifer plants. Russ J Plant Phys 58: 169-173.

Tayer SS, Bjőrkman O (1992) Carotenoid distribution and de-epoxidation in thylakoid pigment-protein complexes from cotton leaves and bundle-sheath cells of maize. Photosynth Res 33: 213-225. 